\title{
IMPLICIT PREDICATIVITY OF NOMINAL SENTENCES IN RUSSIAN AND ENGLISH LANGUAGES
}

\author{
PREDICATIVIDADE IMPLÍCITA DE SENTENÇAS NOMINAIS EM RUSSO E \\ INGLE $S$
}

\author{
PREDICATIVIDAD IMPLÍCITA DE LAS ORACIONES NOMINALES EN LOS \\ IDIOMAS RUSO E INGLÉS
}

\author{
Sitdikova Farida BIZYANOVNA ${ }^{1}$ \\ Kirpichnikova Anna ANDREEVNA ${ }^{2}$
}

\begin{abstract}
The article considers nominal sentences in Russian and English languages. This type of sentences have always been seen as one-member sentences, but in the recent decades some researches have appeared claiming that they contain implicit predicativity, that is, they can be considered as two-member sentences at the level of semantics. The authors completely support this view and explore the way how one member sentences express predicativity using limited language means. The authors also provide the classification of nominal sentences with language examples in Russian and English and express the view that nominal sentences have different degrees of implicit predicativity. Special attention is paid to the kinds of nominal sentences with highest implicit predicativity.
\end{abstract}

KEYWORDS: Nominal sentences. One-member sentences. Existential sentences. Implicit predicativity. Localizer.

RESUMO: $O$ artigo considera sentenças nominais nas línguas russa e inglesa. Este tipo de sentenças sempre foi visto como sentenças de um membro, mas nas últimas décadas algumas pesquisas surgiram alegando que elas contêm uma predicatividade implícita, ou seja, podem ser consideradas sentenças de dois membros no nível da semântica. Os autores apoiam completamente esta visão e exploram a maneira como as sentenças de um membro expressam predicatividade usando meios limitados de linguagem. Os autores também fornecem a classificação de sentenças nominais com exemplos de linguagem em russo e inglês e expressam a visão de que sentenças nominais têm diferentes graus de predicatividade implícita. Atenção especial é dada aos tipos de sentenças nominais com maior predicatividade implícita.

PALAVRAS-CHAVE: Sentenças nominais. Sentenças de um membro. Sentenças existenciais. Predicatividade implícita. Localizador.

RESUMEN: El artículo considera oraciones nominales en los idiomas ruso e inglés. Este tipo de oraciones siempre se han visto como oraciones de un miembro, pero en las últimas décadas

${ }^{1}$ Kazan Federal University (KPFU), Kazan - Russia. Associate Professor of the Department of Foreign Languages. PhD in Linguistics. ORCID: https://orcid.org/0000-0001-9167-1069. E-mail: farida7777@yandex.ru

${ }^{2}$ Kazan Federal University (KPFU), Kazan - Russia. Senior Lecturer of the Department of Foreign Languages. PhD in Philology. ORCID: https://orcid.org/0000-0003-4261-8004. E-mail: kirpanna@yandex.ru 
han aparecido algunas investigaciones que afirman que contienen predicatividad implicita, es decir, pueden ser consideradas como oraciones de dos miembros a nivel semántico. Los autores apoyan completamente este punto de vista y exploran la forma en que las oraciones de un miembro expresan la predicatividad utilizando medios de lenguaje limitados. Los autores también proporcionan la clasificación de oraciones nominales con ejemplos de lenguaje en ruso e inglés y expresan la opinión de que las oraciones nominales tienen diferentes grados de predicatividad implícita. Se presta especial atención a los tipos de oraciones nominales con mayor predicatividad implícita.

PALABRAS CLAVE: Oraciones nominales. Oraciones de un miembro. Oraciones existenciales. Predicatividad implícita. Localizador.

\section{Introduction}

By nominal sentences we mean one-member sentences with the principal part of the sentence expressed by a noun, noun phrase, relative pronoun, nominalized part of speech, or quantitative-nominal word combination where the main word is in the subjective case ${ }^{3}$.

The term comes from the Latin, meaning "name." Nominal sentences can also contain other parts of speech such as articles, adjectives, prepositions and others.

The bright example of a nominal sentence is a line from the poem by famous Russian poet Alexander Blok: Noch. Ulica. Fonar'. Apteka. Night. Street. Lamp. Pharmacy. (GRICE, 1989).

This type of sentences can also be found in English literature, as well.

"And that was what the one who remembered had remembered. War, fear, poverty, typhus and filth [...]" (GARAEVA et al., 2018, p. 180).

Nouns in nominal sentences can be of different kinds: verbal nouns expressing actions (The sound of string quartette.), expressing things (Venetian red hair.), and some characteristics with meaning close to adjectives (Blessed, blessed night.).

According to some authors, nominal sentences were formed from existential sentences through the elimination of localizer. "Nominal sentences are stylistically marked sentences which belong to one type of existential sentences limited in use"4. For example, the sentence "Fields of sunflowers" (GARAEVA et al., 2018, p. 7) is equivalent to: There were fields of sunflowers. The second sentence is made from the first one and has the same meaning but the localizer is missing, it can be understood from the context.

${ }^{3}$ Available: https://www.gbv.de/dms/bs/toc/470048344.pdf. Access: 10 Dec. 2020.

${ }^{4}$ Available: https://dictionary.cambridge.org/dictionary/english/implicit. Access: 10 Dec. 2020. 
Historically this type of sentences was included into one-member sentences. But nowadays more and more researchers share the opinion that nominal sentences can be seen as two-member sentences at the level of semantics. In the 1970-s A.V. Bondarko expressed the idea that the predicativity of nominative sentences is implicit, that is, not expressed. A.V. Bondarko draws attention to this fact in his work "Grammatical category and context" (GRICE, 1975).

N.S. Valgina, who studies nominative sentences nowadays, also considers that they combine the function of naming an object and the idea of its existence, that is, have implicit predicativity.

Implicit and explicit components of the nominal sentences were studied by G.K. Khamzina who dealt with Russian and Tatar languages. She considers these sentences as structurally non-isomorphic to the denotative situation and implicit as well (KOMISSAROV, 2002).

We completely support this point of view and agree that nominal sentences come from existential sentences as a result of the localizer elimination. The localizer in such sentences can be perceived from the context and our background knowledge, as in the example from the Block poem. We also state that implicitness degree in these sentences can vary significantly depending on the characteristics of nouns and try to demonstrate it by language examples.

The problem of implicit predicativity of nominal sentences can be closely connected with the problem of implicitness in general and implicit negation in particular, which we considered in our previous articles (SITDIKOVA; EREMEYEVA; VALIEVA. 2017; PADUCHEVA, 2010). Moreover, this linguistic problem can be considered as a part of pedagogical problem of subjectivity and the unity of subjective language in future specialists' language learning which is investigated by scientists of Kazan Federal University ${ }^{5}$.

Thus, in our article we are focusing on the fact that nominal sentences have implicit predicativity, consisting of explicit subject of the sentence and implicit predicate which can be drawn from the context, situation and the background knowledge.

\section{Methods}

As the theoretical basis of the article we have used the works by L.V. Arnold, N.D. Arutyunova, A.V. Bondarko, V.S. Valgina, E.U. Ivanova, G.K. Khamzina, etc.

5 Available: https://gutenberg.ca/ebooks/maughamws-narrowcorner/maughamws-narrowcorner-00-h.html. Access: 10 Dec. 2020. 
To study nominal sentences, the methods of empirical and theoretical research were applied, for instance analysis, synthesis, comparison, generalization and componential, contextual and comparative methods of research.

We have also collected quite a lot of language examples from Russian and English fiction to illustrate the main points of the article. The Russian examples were transliterated and translated into English for better understanding.

\section{Results and discussion}

We share the view of linguists who claim that nominal sentences are one-member sentences only at the level of grammar but at the level of semantics they can be considered as two-member sentences (KOLSHANSKY, 1980).

In other words, such sentences are characterized by implicit predicativity due to the fact that the context makes these sentences capable of expressing the semantics of actions, especially if there are verbal nouns. This idea is proved by some examples from Russian fiction.

Oh, this is part-time education, god damn it! There were six years of work to death, six years of continuous hard work! Eight hours a day were spent onthe-spot, and then there were four hours of lectures and seminars in the institute! What about homework and assignments? What about exams, pass/fail exams? And how much time was spent going to libraries? (APRESYAN; ORLOV, 2020) ${ }^{6}$

The same examples can be found in English fiction, too:

This was a Pravda editorial: not some fleeting judgement which might be appealed against, but a policy statement from the highest level. Holy writ, in other words (GARAEVA et al., 2018, p. 28).

We also state that different types of nominal sentences possess different degree of hidden predicativity. Nominals with verbal nouns, in our view, have the highest degree of implicit predicativity.

6 'Oh uzh eto vechernee obrazovanie, bud' ono trizhdy proclyato! Shest' letnaiznos, shest' let bespreryvnoi katorgi! Vosem' chasovustanka, chetyre chasa lekcii i seminarov v institute. A podgotovka k zanyatiyam doma? A eksameny, a zachety? A skolko vremeni uchodit na vsyakie razezdy, motaniya po bibliotekam chitalnyam?" (APRESYAN; ORLOV, 2020). 


\section{Verbal nouns}

The ability of nominal sentences to express predicativity is typical for nominative type of languages including Russian and English. The grammar book Modern Russian language.

(Sovremennyi russkii yazyk) suggests that in one-member existential sentences with the principal part of the sentence expressed by verbal nouns the semantics of the existence can be mixed with the semantics of action. For example, "Chrust yablok. Obernulis - loshad' stoit. Chut' pozvyakivaet uzdechka [...]” (SPERBER; WILSON, 1986) (“Apples' crackle. We are turning heads backwards - the horse is standing. Snaffle is clinking slightly [...]"). In the highlighted nominal sentence, there is implicit predicativity, which is represented by verbal noun.

The English language also has verbal nouns, which are close to Russian verbal nouns in meaning. The nominal sentences with verbal nouns can be especially strongly considered as sentences with implicit predicativity. For instance, "The smell of carnation oil [...]" (GARAEVA et al., 2018, p. 7). It should be noted that verbal nouns in English can be made by several ways. The first one is adding -ing (to read - reading), the second is adding special suffixes as -ial (to arrive - arrival), -ment (to develop - development), etc. The other way of conversion is forming new words relating to another part of speech without adding any derivative elements (to test - test) (BENOTTI; BLACKBURN, 2014).

\section{Classification}

There are several classifications of the nominal sentences. We follow the classification which splits them into 4 groups:

1. The first group consists of nominal sentences that provide characteristics of people and objects, for example: 'He was Russia's most famous military strategist: newspapers called him "The Red Napoleon". Also, a music lover and amateur violin maker, a man of open, questioning mind, who enjoyed discussing novels" (GARAEVA et al., 2018, p. 14).

2. The second group includes nominal sentences that provide information about the chain or stages of events: Dekabr, yanvar, fevral...Vot i zima proshla. (December, January, February...The winter is over) [http://www.dialog-21.ru/media/4583/apresjanvjuplusorlovav012.pdf]."Sitting room, bedroom, lumber-room. All as they should be. Nobody under the table, nobody under the sofa [...]" (GARAEVA et al., 2018, p. 115).

3. Sentences of the third group give explanation about some facts, for example: 
- Benzedrine inhaler;

- Benzedrine inhaler?;

- For drug-addict capitalists (GARAEVA et al., 2018, p. 63).

4. The fourth group sentences express disagreement and objection: "He paused for thought. "No, not an intimate friend, but a good friend" (GARAEVA et al., 2018, p. 44).

We consider the last three types as sentences with implicit predicativity. Moreover, unnamed components can be uncovered from the context, situation, lexical valences and general knowledge of the participants of the communicative act.

\section{Object names}

As it was already mentioned, object names used in nominal sentences can get event connotation with support of the context.

Some scientists dealing with this problem in Russian language point out that object nouns can express predicate meanings in some circumstances as well. There are some groups of object names, which can be equivalent of existential sentences. Implicit predicates can be easily revealed if the nouns are:

1) places that are linked with some actions of functions:

Rabota, dom...Dom, rabota...Vot tak I zhizn moya progodit...(Work, home...Home, work. This is the way my life passes... (POCHEPTSOV, 1987).

2) nouns linked our everyday life, e.g. food, clothes, medicines:

Pidzhachok.... Teper' beretka..... On gotov. (Jacket.... Beret next.... He is ready.) (POCHEPTSOV, 1987).

3) nouns with the meaning of movement: Trollebus. I vdrug uzhe vse drugoe. (Trolleybus. And suddenly everything is different) (SITDIKOVA; KHISAMOVA; MUTIGULLINA, 2019).

d) names of material results of human mental activity (novel, book, literary work, etc.) with implicit meaning of predicate "publish", "write", etc.

Zaryadka, progulka i - nauchnye trudy. (Morning exercises, short walk and - scholarly works) (SITDIKOVA; KHISAMOVA; MUTIGULLINA, 2019).

e) different sound effects: phone, radio, alarm sound. 
In general, it should be said that the names objects or things included in everyday life can be regularly used in propositive meaning, that is to express some kind of predicativity. There are two groups of nouns which form nominal sentences with implicit predicativity:

1) nouns which have certain typical function and thus can express semantics of actions linked with them, e.g., Byla disciplina, no bylo veselo. Kino, banya, patefon. (There was a discipline but it was funny. Cinema, bathhouse, phonograph.) (KOZLOVA; KADYROVA; SAKHIBULLINA, 2019).

2) objects with the meaning of work which has to be regularly done, e.g., housework and teacher's work: Kazhdyi den' odno I to zhe: posuda, gryaznoe beljo, rebenok i tetradki, tetradki, tetradki (There was the same thing every day: cookware, dirty clothes, child and copybooks, copybooks, copybooks....) (KOZLOVA; KADYROVA; SAKHIBULLINA, 2019).

Object names are more likely to receive event connotations when they become a part of a chain of events. If it is the chain of objects' names, the event meaning appears via common dynamic context, like in the previous sentence. The ability of object name to express meanings of events can be provided by its closeness with action names and verbal predicate.

"Mrs. Dilber was next. Sheets and towels, a little wearing apparel, two old-fashioned silver teaspoons, a pair of sugar-tongs, and a few boots" (JESPERSEN, 2006, p. 159).

\section{Situation names and proper names}

There is a special group of nouns with the potential of expressing situations or even actions, they hold a specific place - sun, snow, rain, sweat, mess, tears, etc. When included into nominal sentences they often denote not subjects but also situation: Byl teplyi aprel'skii den'. Solnce. Vesna. My sideli s Veroy na Tverskom bulvare, na skameyke. (It was warm April day. Sun. Spring. Vera and I were sitting in Tverskaya Avenue, on a bench). It seems to be the only group of objects' names capable to be used without context support (FILLMOR, 1981, p. 144).

Proper names are capable to become a marker of the situation if they provide stable associations. For instance, the names of geographical objects where some historically important events happened or are happening right now are the most common. Among them, there are war places, cities where the most terrible battles took place etc. 
"Vittoria, Salamanca, Toulouse, Moodkee, Ferozzhah, an' Sobraon - that was fought close next door here, against the very beggars he wants us to join. Inkerman, The Alma, Sebastopol!" (MAUGHAM, 2019, p. 77).

Event-related connotations can be given to names of famous people and fictional characters.

"Comrade Stalin would be there, also Comrades Molotov, Mikoyan and Zhdanov" (GARAEVA et al., 2018, p. 19).

"Nikita the Corncob. Who would go into tirades about 'abstractionists and pederasts' they being obviously the same thing" (GARAEVA et al., 2018, p. 130).

We should note that these connotations related with some historical events can exist only for people with the same culture and background knowledge.

Drawing the hidden meaning of non-verbal components is possible owing to the situation, general knowledge and the background knowledge of participants.

\section{Nominal sentences functioning}

Nominal sentences are widely used in literary language and conversational speech because of their conciseness, expressiveness and the ability to produce different associations.

They are often used as newspaper and books headlines. For example, Greg Mortenson and David Oliver Relin's book (SALINGER, 2020) tells about a man's quest to promote peace by sharing "three cups of tea" with various individuals in Pakistan. So, this noun is associated with an action - it means three cups of tea than Mortenson shared with the others.

Nominal sentences are widely used in fiction and poetry. The style of some poets is based on compacting information and using the subtext. For example, a Russian poet M.T Zvetaeva used a lot of nominal sentences, thus transmitting a large amount of information a small-sized text (YUS, 2020).

In conversational speech nominal sentences are often used for economical expression of different ideas, for example: Morning! (Greeting) Scalpel! (Request) or Fire! (Warning).

Proverbs are often expressed in a form of nominal sentences. For example: More haste, less speed. When translated into Russian, this sentence contains verbs: Pospeshish, lyudei nasmeshish. From our practical experience of translating fiction we know that some implicit structures become explicit as a result of translation to another language. So the fact of appearing verbs in the translation of the English proverb evidences about the hidden (implicit) predicativity of the English sentence. 


\section{Summary}

Nominal sentences are widely used in conversational speech, fiction and poetry. They allow speak out ideas in a short, concise way leaving a part of information implicit, but it can be understood by speakers due to the situation, context and common knowledge of the world.

The problem of nominal sentences in linguistics has not been sufficiently developed. Many types of nominal sentences, considered to have one member, at the deep semantic level combine the function of naming an object and the idea of its existence, that is, have implicit predicativity.

We support the view that nominal sentences with some contextual support can implicitly have the meaning of action. The property of nominal sentences to express predicativity is common to all languages of the nominative type, including Russian and English.

\section{Conclusions}

1. Some linguists suppose that nominal sentences have derived from existential sentences due to the elimination of the localizer. This view seems quite reasonable to us.

2. The semantic nature is extremely important for nominal sentences. First of all, these should be words that describe phenomena and objects that are available to visual-sensory perception. Secondly, these are the names of objects located in some particular space which are clear due to background knowledge. Thirdly, these are verbal nouns that also express hidden predicativity.

3. Nominal sentences with event-related nouns, potentially indicative nouns denoting situations, and also proper names associated with well-known events possess especially high implicit predicativity.

4. Some names of objects and things can also express predicativity, when they form a chain expressing events.

5. Comprehension of non-verbalized components in nominative sentences by communicants occurs in most cases due to the situation, context and common knowledge of the world and the associative base of communicants.

6. Nominative sentences are one of the manifestations of implicitness, which is the most important feature of all natural languages, allowing to express ideas in a short and compact form. 
ACKNOWLEDGEMENTS: The work is performed according to the Russian Government Program of Competitive Growth of Kazan Federal University.

\section{REFERENCES}

APRESYAN, V. Y.; ORLOV, A. V. Semanticheskiye tipy implicatur i usloviya ih vozniknoveniya. 2020. Available: http://www.dialog21.ru/media/4583/apresjanvjuplusorlovav-012.pdf. Access: 10 Dec. 2020.

BENOTTI, L.; BLACKBURN, P. Context and implicature. 2014. Available:

https://www.researchgate.net/publication/312676945_Context_and_Implicature. Access: 10 Dec. 2020.

CAMBRIDGE Advanced Learner's Dictionary. Available:

https://dictionary.cambridge.org/dictionary/english/implicit. Access: 10 Dec. 2020.

FILLMOR, C. J. Frame semantics. SICOL, 1981.

GARAEVA, A. K. et al. Awareness of historical background as one of the factors of better language acquisition. International Journal of English Language and Literature Studies, v. 7, n. 1, p. 15-21, 2018.

GRICE, P. Logic and conversation. In: COLE, P.; MORGAN, J. L. (Eds.). Syntax and semantics. New York: Academic Press, 1975. v. 3, p. 41-58.

GRICE, P. Studies in the way of words. Harvard University Press, 1989.

JESPERSEN, O. The philosophy of grammar. Routledge, 2006

KASHICHKIN, A. V. Implitzitnost v kontexte perevoda: dis. ... kand. filol. nauk: 10.02.20. Moscow, 2013.

KOLSHANSKY, T. V. Kontextnaya semantika. Moscow: Nauka, 1980.

KOMISSAROV, V. N. Sovremennoe prrevodovedeniye. Moscow: ETC, 2002.

KOZLOVA, Y. A.; KADYROVA, A. A.; SAKHIBULLINA, K. A. Problems of testing application in foreign language learning control. Humanities and Social Sciences Reviews, v. 7 , n. 6 , p. 53-59, 2019.

MAUGHAM, W. S. Narrow corner. 2020. Available:

https://gutenberg.ca/ebooks/maughamws-narrowcorner/maughamws-narrowcorner-00-h.html. Access: 10 Dec. 2020.

MAUGHAM, W. S. The painted veil. 2019. Available: https://www.reads2019.com/paintedveil. Access: 10 Dec. 2020. 
PADUCHEVA, E. V. Viskazivaniye i ego sootnesennost' s deistvitel'nostyu. Moscow: LKI, 2010.

POCHEPTSOV, G. G. Kommunikativniye aspekti semantiki. Kiev: Vishcha Shkola, 1987.

SALINGER, J. D. The catcher in the rye. 2020. Available:

http://masterrussian.net/f49/catcher-rye-j-d-salinger-english-russian-12212/. Access: 10 Dec. 2020 .

SHELDELS, E. I. Implicitnost v grammatike. In: SHENDELS, E. I. Voprosy romanogermanskoy philologii. Sintaksicheskaya semantika: sbornik nauchnikh trudov MGPIIY imeni M.Toreza. Moscow, 1977. p. 37-45.

SITDIKOVA, F. B.; EREMEYEVA, G. R.; VALIEVA, G. F. Implicit negation in dialogue discourse. Journal of History Culture and Art Research, v. 6, n. 6, p. 175-181, 2017.

SITDIKOVA, F. B.; KHISAMOVA, V. N.; MUTIGULLINA, Z. A. Implicit negation in tatar phraseology. Journal of Sociology and Social Anthropology, v. 10, n. 4, p. 175-179, 2019.

SPERBER, D.; WILSON, D. Relevance. Inference and Implicature. In: SPERBER, D.; WILSON, D. Meaning and interpretation. Oxford, 1986. p. 43-75.

THOMAS, J. Meaning in interaction: an introduction to pragmatics. Longman, 1995

YUS, F. Misunderstandings and explicit/implicit communication. Available:

https://benjamins.com/catalog/prag.9.4.01yus/fulltext/prag.9.4.01yus.pdf. Access: 10 Dec. 2020.

How to reference this article

BIZYANOVNA, S. F.; ANDREEVNA, K. A. Implicit predicativity of nominal sentences in russian and english languages. Rev. EntreLínguas, Araraquara, v. 7, n. esp. 3, e021050, Sep. 2021. e-ISSN: 2447-3529. DOI: https://doi.org/10.29051/el.v7iesp.3.15708

Submitted: 10/01/2021

Required revisions: 20/03/2021

Approved: 23/06/2021

Published: 01/08/2021 